\title{
Development and validation of scale for measuring attitudes towards e- professionalism among medical and dental students: SMePROF-S scale
}

\author{
Marko Marelićc ${ }^{*}$, Joško Viskić, Lovela Machala Poplašen ${ }^{1}$, Danko Relić ${ }^{1}$ Dražen Jokić and Tea Vukušić Rukavina ${ }^{1}$
}

\begin{abstract}
Background: Social media permeated everyday life and consequently it brought some changes to behaviour of health professionals. New form of professionalism emerged called e-professionalism depicting professional behaviour while using social media. There are a number of studies conducted in the past several years measuring behaviour of different populations of health professionals on social media and social media sites. Many studies have investigated aspects of e-professionalism of medical or dental students as future health professionals, but there are no validated instruments made for assessing attitude towards e-professionalism of those two populations. Objective of this paper is to validate a newly developed scale for measuring attitudes towards e-professionalism among medical and dental students.
\end{abstract}

Methods: The original 32-item scale was developed and administered to 411 medical students (RR 69\%), and 287 dental students (RR 49.7\%). Exploratory factor analysis was used to investigate the existence of underlying factors. Principal component analysis was used as an extraction method with oblimin as selected oblique rotation method. Cronbach's alpha was used to assess reliability.

Results: Total of 698 student answers entered analysis. The final scale had 24 items that formed seven factors named: ethical aspects, dangers of social media, excluding physicians, freedom of choice, importance of professionalism, physicians in the digital age, negative consequences. Cronbach's alpha indicating scale reliability was .72. Reliability conducted on each factor ranged from .570 to .877 .

Conclusions: The scale measures seven factors of attitude towards e-professionalism and exhibits satisfactory reliability. Based on insights from validation, some possible improvements are suggested.

Keywords: E-professionalism, Factor analysis, Attitude scale, Validation, Social media, dental students, medical students

\footnotetext{
* Correspondence: marko.marelic@snz.hr

${ }^{1}$ School of Medicine, University of Zagreb, Zagreb, Croatia

Full list of author information is available at the end of the article
}

C C The Author(s). 2021 Open Access This article is licensed under a Creative Commons Attribution 4.0 International License, which permits use, sharing, adaptation, distribution and reproduction in any medium or format, as long as you give appropriate credit to the original author(s) and the source, provide a link to the Creative Commons licence, and indicate if changes were made. The images or other third party material in this article are included in the article's Creative Commons licence, unless indicated otherwise in a credit line to the material. If material is not included in the article's Creative Commons licence and your intended use is not permitted by statutory regulation or exceeds the permitted use, you will need to obtain permission directly from the copyright holder. To view a copy of this licence, visit http://creativecommons.org/licenses/by/4.0/ The Creative Commons Public Domain Dedication waiver (http://creativecommons.org/publicdomain/zero/1.0/) applies to the data made available in this article, unless otherwise stated in a credit line to the data. 


\section{Background}

The emergence of social networks sites as a new form of digital media and communication channel has brought many challenges for the health system [1-3]. The widespread use of social media affects the context in which professional behaviours are exhibited and how they are interpreted [4].

Professionalism is broadly defined as behaviour in accordance with professional and ethical standards of the profession and can be evaluated through ten components: professional competence, honesty in doctorpatient relationship, health professional-patient privacy, maintaining a proper relationship with the patient, improving the quality of health care, improving the availability of health care, fair distribution of resources, evidence-based knowledge, maintaining patient confidence (prevention of conflict of interest) and professional responsibility [5].

E-professionalism is a derived form of professionalism and can be defined as implementation of traditional principles of professionalism during online activities. Furthermore, it can be defined as a commitment to carry out professional tasks while adhering to ethical principles and care for the patient's well-being during online social activities [4].

The effort to understand and improve eprofessionalism of health professionals on social media sites is visible in the commitment that large number of medical and educational institutions make through various guidelines and advices for online behaviour. Some form of guidelines for e-professionalism are published or available online by a large number of institutions: The American Medical Association [6], The Australian and New Zealand Medical Association [7], The British Medical Association [8] and many others.

First research related to e-professionalism appeared in 2008; in a synthetic review published in 2015 search strategy combine terms "professionalism" with "internet" or "social media" in any field in PubMed, CINAHL and Google Scholar, 941 papers were found, published between 2010 and 2014, of which about thirty that tackle professionalism of healthcare workers on the Internet [9].

The number of users of social media sites grows rapidly so interest in understanding e-professionalism has to follow. Facebook alone currently has over 2.7 billion users active on a monthly basis [10]. If we consider that according to some research about $87 \%$ of doctors of medicine have a private account on social networks, and $67 \%$ maintain a professional account [11], it is evident that e-professionalism has become an important issue.

In most studies that have health professionals in the sample, the sample is composed of a one specific profession, for example urologists [12], paediatricians [13], surgeons [14], psychotherapists [15] or nurses [16]. A common research question in those studies is how many respondents use social networks and why they use them. Some papers focus on attitude towards social networks, mainly as a review of the benefits and dangers of using social networks for professional or educational purposes.

One study by Chisholm-Burns et al. designed and validated scale for measuring attitudes towards social media professionalism on pharmacy students [17]. After validation, instrument had 22 items that formed five factors named: honesty and integrity, respect for others, accountability, duty, and excellence. Cronbach's alpha measuring reliability of instrument was .72 . Scale covered a broad range of topics: classroom behaviours, conduct such as posting about unprofessional behaviour to social media sites, and the authority of the college/university in monitoring and penalizing students' social media behaviours.

Even though many studies have investigated aspects of e-professionalism of medical or dental students [18-22], and some investigated attitude towards social media professionalism on similar but different populations [17, 23], so far none of the validated instruments has been made for assessing attitude towards e-professionalism of medical and dental students.

Medical and dental profession have some key similarities that justify comparing them in the field of professionalism. Whilst distinct, dentistry shares many of the ethical foundations of medicine, such as the Hippocratic promise of best interest, confidentiality and respect for autonomy. The dentist/physician-patient relationship, much as is an intimate and personal one, demanding high levels of trust [24].

Regardless of similarities there are some key differences that might result in different attitudes towards eprofessionalism. Dentistry is in some aspects considered being closer to cosmetic surgery or business professions, such as low and accountancy. Dentistry is more market oriented, and coupled with different cosmetic treatment options such as bleaching, aesthetic crowns and orthodontics it has created a market based on want rather than needs [24].

The disproportion of medical and dental students' orientation towards private sector is documenter in UK study on dental undergraduate students who expressed that different expectations are places on dental students regarding SM use compared to medical students given that dentistry is a business [25].

Because of those reasons we believe dental students tend to be more open towards patients on SM, which makes them prone to bigger risk of e-professionalism violation.

The aim of this study is to develop and validate a scale for the assessment of attitude towards e-professionalism 
in medical students and dental students that could be used not only to measure attitude but also to compare those attitudes of these two populations. Results obtained from this research will be used to create and implement guidelines for e-professional behaviour for medical and dental students during their education, rather than for disciplinary purposes.

\section{Subjects and methods}

The instrument for measuring attitude towards eprofessionalism among medical and dental students is part of the larger questionnaire "Exploring the impact of social networks on the professional behaviour of healthcare professionals" conducted for research on project Dangers and benefits of social networks: e-professionalism of healthcare professionals (SMePROF project [26]). As a part of the project a quantitative cross-sectional study on the use of SM, attitudes and ethical values of students was carried out in the School of Medicine University of Zagreb, Croatia (UZSM) and the School of Dental Medicine University of Zagreb, Croatia (UZSDM) in the academic year 2018/2019.

Students were informed about the possibility of completing the questionnaire (UZSM 2nd and 5th year, and at the UZSDM students of all 6 years of study) during regular classes. Identification information or IP addresses were not collected to ensure anonymity. All participants were informed in guidelines statement that their participation is voluntary and anonymous. The first question of the questionnaire was informed consent about participation, allowing students that do not want to participate to opt out. Students that gave electronic informed consent on that question entered the sample. Both research and questionnaires were approved by the Ethical board of University of Zagreb School of Medicine, issued on March 22nd 2018 (641-01/18-02/01) and Ethical board of University of Zagreb School of Dental Medicine, issued on February 20th 2018 (05-PA24-2/2018). All methods were carried out in accordance with relevant guidelines and regulations.

The questionnaire was composed of seven instruments that measured as follows: (1) sociodemographic characteristics and habits of SM usage; (2) knowledge of SM; (3) reasons of SM usage; (4) impression management on SM; (5) security on SM; (6) attitudes towards professionalism; and (7) attitudes towards e-professionalism. This paper covers validation of the seventh instrument that measures students' attitudes towards e-professionalism.

The instrument was initially composed of 32 items. All items were taken from previous research conducted on similar topics and translated to Croatian language.

Bosslet et al. measured patient-doctor relationship on online social networks with segment dedicated to ethical questions of patient-doctor communication [27].
Therefore, items 1 thru 5 (as shown in Table 1) were taken from their research.

In similar research, White et al. measured attitudes to guidelines relating Facebook use [28]. Total of 21 items were taken from their research, out of which 18 entered the final scale (6 thru 18 and 22 thru 24), and 5 items that didn't $(25,26,29,30,31$ as shown in Table 2).

Three items (19 thru 21) measuring the aspect of responsibility towards guiding patients on social networks were taken from the study of Kitsis et al., as well as two items that were not included in the final version $(27,28$ as shown in Table 2) [2].

In order to assess the developed scale, it was administered to 714 students at the School Medicine and School of Dental Medicine, University of Zagreb, Croatia in the period from 10th of November 2018 to the 4th of January 2019. After screening results, 698 answers entered the analysis.

Before administering, content validity was reviewed and affirmed by the research team of experts from various scientific fields: sociologist, doctor of medicine, doctors of dental medicine, psychiatrist and communicologist. Following the example of Ichikawa et al., six researchers repeatedly checked whether items represented e-professionalism, whether item content was suitable for judging attitude towards e-professionalism of dental and medical students, and whether concept of e-professionalism was covered in the entire scale [29]. The researchers agreed that all items included in this scale reflected attitude towards e-professionalism.

Data analysis was performed using IBM SPSS statistics 25. Demographic data were summarized as descriptive statistics.

Construct validity was investigated using exploratory factor analysis, followed by scale reliability analysis using Cronbach's alpha coefficient of the internal consistency. In an iterative process of repeating dimensionality analysis and reliability analysis after each item that was discarded instruments was improved and validated. Internal consistency was investigated for each factor and for the instrument as a whole.

As the extraction method, principal component analysis was used with oblimin as selected oblique rotation method.

\section{Results}

Study sample

Of the 714 collected students' responses a total of 698 entered analysis, 411 from second and fifth-year medical students (RR 69\%), and 287 from first to sixth year dental students (RR 49.7\%); mean age of 22, range 18 to 30 years, $74 \%$ of the students were female and $26 \%$ were male. 
Table 1 Average questions scoring, answers range from $1=$ completely disagree to $5=$ completely agree Items

1 It is ethically acceptable for a physician to communicate with a patient through social media as part of his/her care for patients and the patient healthcare process. ${ }^{a}$

2 It is ethically acceptable for a physician to communicate (e.g. share personal messages) with a patient through personal social 3.25 media account for easier social interaction. ${ }^{\text {a }}$

3 Social media have the potential to improve communication between a physician and a patient. ${ }^{\text {a }}$

4 Communication with a patient through social media can be achieved without compromising physician-patient confidentiality. ${ }^{a}$

5 It is ethically acceptable for a physician to visit patient social media profile. ${ }^{a}$

6 It is possible that your potential employer will not hire you or invite you for an interview due to information about you found online.

7 There is a possibility that your online behaviour might have an impact on perception of others in your profession.

8 People can make wrong assumptions about you based solely on the content of your post.

9 You may lose a position you already hold (as an employee or student) due to information about you found online.

10 Sharing privileged patient information on social media without their consent is deemed to be inadmissible.

11 Healthcare professionals should be banned from using social networking software due to too much of a risk. ${ }^{a}$

12 Healthcare professionals should be restricted from using social networking software due to too much of a risk. ${ }^{a}$

13 I should be able to do whatever I want online. ${ }^{a}$

14 The School has no right to interfere in my online activities. ${ }^{a}$

15 I believe that my online activities do not affect me as a professional. ${ }^{a}$

16 I strongly agree with expectations for professional behaviour and make a conscious effort to comply with them in every aspect of my life. ${ }^{a}$

17 I know well what constitutes professional behaviour and what is expected of me as a current/future professional. ${ }^{\text {a }}$

18 High-level professional behaviour should also be expected of students from the very beginning of their studies.

19 Guiding patients to online information is a new responsibility of physicians in the digital age. ${ }^{\text {a }}$

20 As a medicine / dental medicine graduate, it is my obligation to keep abreast with the current trends in the use of social media. ${ }^{a}$

21 One of the responsibilities of a teacher is to counsel students on the appropriate use of social media. ${ }^{a}$

22 Professionals cannot actually fully relax. ${ }^{a}$

Table 2 Items excluded after validation

\begin{tabular}{lll}
\hline Items & Reason for exclusion \\
\hline 25 & People have the opportunity to post photos and document aspects of & Low saturation on all factors \\
their professional life which would otherwise remain private. & \\
26 & $\begin{array}{l}\text { A little leniency should be shown if unprofessional behaviour occurs in } \\
\text { the first years of professional education. }\end{array}$ & Not contributing to one factor; low inter-item correlation; \\
27 & The risks of social networking software greatly overweigh the benefits. & Equally low contribution to all factors \\
28 & Patients use social media to get medical / dental information. & Ambiguous direction of item, not contributing to one factor \\
29 & $\begin{array}{l}\text { Professionalism in online activities is as important as in traditional } \\
\text { (offline) environments. }\end{array}$ & Low contribution to multiple factors \\
30 & I believe discussion on online professionalism to be more important for \\
my profession than for any other. & These two items form specific dimension that stays uncorrelated with \\
31 & I believe discussion on online professionalism to be more important for \\
my healthcare profession (physicians of different specialties) in respect & professionalism \\
to any other profession. & \\
32 & The benefits of social media overweight the risks of their use. & Equally low contribution to multiple factors \\
\hline
\end{tabular}


In order to provide a better picture about this convenience sample three variables were measured: active or passive type of usage, frequency of access and type of device most used.

\section{Development, reliability and validity of SMePROF-student version (SMePROF-S) scale}

Construct validity was tested with exploratory factor analysis that was conducted on 32-item scale. KaiserMeyer-Olkin measure (.771) and Bartlett's test of sampling adequacy $\left(x^{2}=6873.78, \mathrm{df}=496, p=0.000\right)$ shows that dimension reduction is applicable on this data. Initial factor analysis extracted nine factors that cumulatively explained $62.8 \%$ of total variance. Reliability of the initial 32-item scale was $\alpha=.765$.

One item (25 - People have the opportunity to post photos and document aspects of their professional life which would otherwise remain private) was removed because it did not measure attitude and it saturated equally on multiple factors. In following iteration, item (26-A little leniency should be shown if unprofessional behaviour occurs in the first years of professional education) was removed because it didn't have adequate saturation on neither of factors, probably because overall very positive score on this sample (about $85 \%$ of students agreed). Additional six items were deleted because they failed to load on any of the factors.

Final scale consists of 24 items and factor analysis produced seven factors explaining $65.53 \%$ of cumulative variance that can be logically described (Table 3 ). Cattel's scree test confirmed the same number of factors as the Kaiser criterion (eigenvalue greater than one).

Reliability analysis was conducted on final scale and Cronbach coefficient was $\alpha=.72$, furthermore, reliability of each factor was conducted separately and $\alpha$ coefficients ranged from .570 to .877 as it is shown in Table 3 .

The first factor is called Ethical aspects and five items in this dimension measure attitudes towards ethical aspects of communicating with patients via social networks. It encompasses whether it is ethically acceptable to communicate with patients through social networks and does social media have the potential to improve communication between physician and a patient.

The second factor is called Dangers of $S M$ and it is composed by five items measuring perceived negative impact of social networks on future (or current) employment, as well as possibility that people can make wrong assumptions based on the content of one's posts.

The third factor named Excluding physicians measures attitude towards prohibiting or restricting usage of social networks to medical workers.

The fourth factor named Freedom of choice is formed by three variables measuring independence of acting (and posting on social media) from college rules and social rules, suggesting that online activities do not affect their professional performance.

The fifth factor named Importance of professionalism is connecting e-professionalism to "offline" professionalism (or professional behaviour as already known concept). Factor is formed by items describing need for professional behaviour as well as self-assessment about what constitutes professional behaviour.

The sixth factor, Physicians in the digital age, measures attitude towards positive inclusion of social networks in the medical profession, making physicians and medical teachers responsible for education and guidance of patients and students in tenants of "correct" type of network usage.

The seventh factor called Negative consequences is formed by three items and encompasses overall negative attitudes toward changes that social networks brought; namely in protection of physicians from public and inabilities to fully relax and maintain professional image.

Second-order factor analysis conducted on factor scores from obtained seven factors was used to further describe the dimensionality of the instrument. Seven factors are grouped in four second-order factors, as it is shown in Table 4. It's important to notice that factor $E x$ cluding physicians does not group with other factors.

Inspection of average question scoring provided in Table 1, can be used to further clarify the attitudes of students in this sample. Since this scale was part of the larger questionnaire with multiple instruments, some items were measured on a five-point scale, and some were measured on a four item scale (without the neutral answer). That is the reason for the somewhat larger standard deviation on later type of items. The highest degree of agreement was on the item 10 - Sharing privileged patient information on social media without their consent is deemed to be inadmissible. Suggesting that there is no ambiguity about ethical perspective of dealing with privileged information, also supported with a high degree of agreement with item 17 that states that they know what constitutes professional behaviour and what is expected of me as a current/future professional. However, attitude toward teachers being one responsible for counselling students on the appropriate use of social media did not have such uniform consent and using sanctions for misbehaviour (like banning or restricting medical professionals from social networks) were items with the largest degree of disagreement.

\section{Discussion}

As far as authors know this is the first scale designed to investigate attitudes towards e-professionalism on student population of medicine and dental medicine.

Scale demonstrated acceptable reliability score $(\alpha=$ .72). Values of Cronbach alpha used in this study in 
Table 3 Principal components analysis with corresponding Cronbach a coefficients for each factor

\begin{tabular}{|c|c|c|c|c|c|c|c|c|}
\hline \multirow[b]{3}{*}{ Factors } & \multirow[b]{3}{*}{ Items } & \multicolumn{7}{|l|}{ Factors } \\
\hline & & $\begin{array}{l}\text { Ethical } \\
\text { aspects }\end{array}$ & $\begin{array}{l}\text { Dangers } \\
\text { of SM }\end{array}$ & $\begin{array}{l}\text { Excluding } \\
\text { physicians }\end{array}$ & $\begin{array}{l}\text { Freedom } \\
\text { of choice }\end{array}$ & $\begin{array}{l}\text { Importance of } \\
\text { professionalism }\end{array}$ & $\begin{array}{l}\text { Physicians } \\
\text { in the } \\
\text { digital age }\end{array}$ & $\begin{array}{l}\text { Negative } \\
\text { consequences }\end{array}$ \\
\hline & & 1 & 2 & 3 & 4 & 5 & 6 & 7 \\
\hline \multirow[t]{5}{*}{ Ethical aspects } & $\begin{array}{l}\text { It is ethically acceptable for a } \\
\text { physician to communicate with a } \\
\text { patient through social media as part } \\
\text { of his/her care for patients and the } \\
\text { patient healthcare process. }\end{array}$ & .885 & .020 & -.067 & .030 & .008 & .162 & .022 \\
\hline & $\begin{array}{l}\text { It is ethically acceptable for a } \\
\text { physician to communicate (e.g. } \\
\text { share personal messages) with a } \\
\text { patient through personal social } \\
\text { media account for easier social } \\
\text { interaction. }\end{array}$ & .870 & .072 & -.080 & .076 & .006 & .136 & .018 \\
\hline & $\begin{array}{l}\text { Social media have the potential to } \\
\text { improve communication between a } \\
\text { physician and a patient. }\end{array}$ & .865 & .100 & -.127 & .024 & .059 & .243 & .021 \\
\hline & $\begin{array}{l}\text { Communication with a patient } \\
\text { through social media can be } \\
\text { achieved without compromising } \\
\text { physician-patient confidentiality. }\end{array}$ & .832 & .041 & -.101 & .013 & .012 & .191 & .078 \\
\hline & $\begin{array}{l}\text { It is ethically acceptable for a } \\
\text { physician to visit patient social } \\
\text { media profile. }\end{array}$ & .625 & .086 & -.030 & .122 & -.021 & .108 & .067 \\
\hline \multirow[t]{5}{*}{ Dangers of SM } & $\begin{array}{l}\text { It is possible that your potential } \\
\text { employer will not hire you or invite } \\
\text { you for an interview due to } \\
\text { information about you found online. }\end{array}$ & .109 & .838 & -.073 & -.040 & .065 & .101 & -.114 \\
\hline & $\begin{array}{l}\text { There is a possibility that your online } \\
\text { behaviour might have an impact on } \\
\text { perception of others in your } \\
\text { profession. }\end{array}$ & .037 & .827 & -.049 & -.025 & .185 & .120 & -.177 \\
\hline & $\begin{array}{l}\text { People can make wrong } \\
\text { assumptions about you based solely } \\
\text { on the content of your post. }\end{array}$ & .050 & .821 & -.102 & -.016 & .176 & .105 & -.103 \\
\hline & $\begin{array}{l}\text { You may lose a position you already } \\
\text { hold (as an employee or student) } \\
\text { due to information about you found } \\
\text { online. }\end{array}$ & .040 & .773 & .018 & -.051 & .087 & .124 & -.067 \\
\hline & $\begin{array}{l}\text { Sharing privileged patient } \\
\text { information on social media without } \\
\text { their consent is deemed to be } \\
\text { inadmissible. }\end{array}$ & .108 & .588 & -.379 & .102 & .166 & .044 & -.028 \\
\hline \multirow[t]{2}{*}{$\begin{array}{l}\text { Excluding } \\
\text { physicians }\end{array}$} & $\begin{array}{l}\text { Healthcare professionals should be } \\
\text { banned from using social } \\
\text { networking software due to too } \\
\text { much of a risk. }\end{array}$ & -.091 & -.140 & .896 & .034 & .076 & .016 & -.131 \\
\hline & $\begin{array}{l}\text { Healthcare professionals should be } \\
\text { restricted from using social } \\
\text { networking software due to too } \\
\text { much of a risk. }\end{array}$ & -.116 & -.028 & .870 & -.101 & .122 & .108 & -.219 \\
\hline \multirow[t]{3}{*}{$\begin{array}{l}\text { Freedom of } \\
\text { choice }\end{array}$} & $\begin{array}{l}\text { I should be able to do whatever I } \\
\text { want online. }\end{array}$ & .074 & -.010 & -.088 & .788 & -.063 & -.040 & -.198 \\
\hline & $\begin{array}{l}\text { The School has no right to interfere } \\
\text { in my online activities. }\end{array}$ & .021 & .023 & -.245 & .733 & -.069 & -.144 & -.324 \\
\hline & $\begin{array}{l}\text { I believe that my online activities do } \\
\text { not affect me as a professional. }\end{array}$ & .057 & -.057 & .113 & .687 & .168 & .059 & .076 \\
\hline Importance of & I strongly agree with expectations & .012 & .138 & .067 & .044 & .874 & .045 & .012 \\
\hline
\end{tabular}


Table 3 Principal components analysis with corresponding Cronbach a coefficients for each factor (Continued)

\begin{tabular}{|c|c|c|c|c|c|c|c|c|}
\hline \multirow[b]{3}{*}{ Factors } & \multirow[b]{3}{*}{ Items } & \multicolumn{7}{|l|}{ Factors } \\
\hline & & $\begin{array}{l}\text { Ethical } \\
\text { aspects }\end{array}$ & $\begin{array}{l}\text { Dangers } \\
\text { of SM }\end{array}$ & $\begin{array}{l}\text { Excluding } \\
\text { physicians }\end{array}$ & $\begin{array}{l}\text { Freedom } \\
\text { of choice }\end{array}$ & $\begin{array}{l}\text { Importance of } \\
\text { professionalism }\end{array}$ & $\begin{array}{l}\text { Physicians } \\
\text { in the } \\
\text { digital age }\end{array}$ & $\begin{array}{l}\text { Negative } \\
\text { consequences }\end{array}$ \\
\hline & & 1 & 2 & 3 & 4 & 5 & 6 & 7 \\
\hline \multirow[t]{3}{*}{ professionalism } & $\begin{array}{l}\text { for professional behaviour and make } \\
\text { a conscious effort to comply with } \\
\text { them in every aspect of my life. }\end{array}$ & & & & & & & \\
\hline & $\begin{array}{l}\text { I know well what constitutes } \\
\text { professional behaviour and what is } \\
\text { expected of me as a current/future } \\
\text { professional. }\end{array}$ & .019 & .151 & -.025 & .139 & .824 & -.059 & -.076 \\
\hline & $\begin{array}{l}\text { High-level professional behaviour } \\
\text { should also be expected of students } \\
\text { from the very beginning of their } \\
\text { studies. }\end{array}$ & .000 & .126 & .190 & -.130 & .736 & .221 & .035 \\
\hline \multirow[t]{3}{*}{$\begin{array}{l}\text { Physicians in } \\
\text { the digital age }\end{array}$} & $\begin{array}{l}\text { Guiding patients to online } \\
\text { information is a new responsibility } \\
\text { of physicians in the digital age. }\end{array}$ & .266 & .058 & .073 & .009 & -.013 & .768 & -.060 \\
\hline & $\begin{array}{l}\text { As a medicine / dental medicine } \\
\text { graduate, it is my obligation to keep } \\
\text { abreast with the current trends in } \\
\text { the use of social media. }\end{array}$ & .165 & .076 & -.130 & .073 & .088 & .759 & -.153 \\
\hline & $\begin{array}{l}\text { One of the responsibilities of a } \\
\text { teacher is to counsel students on } \\
\text { the appropriate use of social media. }\end{array}$ & .068 & .191 & .181 & -.140 & .090 & .649 & .028 \\
\hline \multirow[t]{3}{*}{$\begin{array}{l}\text { Negative } \\
\text { consequences }\end{array}$} & $\begin{array}{l}\text { Professionals cannot actually fully } \\
\text { relax. }\end{array}$ & -.105 & .160 & .145 & .034 & -.005 & .093 & -.831 \\
\hline & $\begin{array}{l}\text { Social media have removed } \\
\text { protection of professionals against } \\
\text { the public. }\end{array}$ & -.063 & .097 & .209 & .015 & .088 & .082 & -.798 \\
\hline & $\begin{array}{l}\text { It is not always possible to maintain } \\
\text { professionalism in online activities. }\end{array}$ & .042 & .072 & .001 & .339 & -.018 & .044 & -.653 \\
\hline \multicolumn{2}{|c|}{ Cronbach a coefficients } & .877 & .829 & .823 & .601 & .748 & .570 & .680 \\
\hline
\end{tabular}

order to demonstrate degree of internal consistency can lie between 0 and 1, and values between 0.7 and 0.9 are interpreted as acceptable reliability [30].

Final scale that was developed through validation is composed of 24 variables and yielded seven factors that collectively explained $65.53 \%$ of cumulative variance. Reliability of each factor was conducted separately and $\alpha$ coefficients ranged from .570 to .877 . Coefficients that

Table 4 Second order factors analysis, a structure matrix

\begin{tabular}{lllll}
\hline & \multicolumn{5}{l}{ Second order factors } \\
\cline { 2 - 5 } Factors & $\mathbf{1}$ & $\mathbf{2}$ & $\mathbf{3}$ & $\mathbf{4}$ \\
\hline Ethical aspects & $\mathbf{. 8 0 3}$ & -.284 & -.034 & .056 \\
Physicians in the digital age & $\mathbf{. 7 3 2}$ & .333 & .017 & -.240 \\
Excluding physicians & -.038 & $\mathbf{. 8 6 9}$ & .028 & .005 \\
Negative consequences & .040 & -.258 & $\mathbf{. 7 7 2}$ & .180 \\
Freedom of choice & .062 & -.294 & -.741 & .136 \\
Dangers of SM & .161 & -.183 & -.105 & $-\mathbf{. 7 7 1}$ \\
Importance of professionalism & .000 & .178 & .044 & $-\mathbf{. 7 0 7}$ \\
\hline
\end{tabular}

have lower values than 0.7 are likely results of a small number of items that form them (factor Physicians in digital age is formed by only two variables and has lowest consistency with $\alpha=.570$ ). Authors recommend increasing the number of items measuring that specific dimension in order to improve scale.

Several factors found in this scale match some of the tenants of (traditional) professionalism defined by ABIM foundation [5]. This can be understood as a form of verification of definition of e-professionalism, since we had no empirical guarantee what exact factors would reflect in phenomenon of e-professionalism. Protecting a patient's privacy and maintaining proper relationships with patients defined as tenants of professionalism can be seen in e-professionalism scale as factors Dangers of $S M$ and Ethical aspects. Furthermore, improving the quality of healthcare can be seen in factor Physicians in the digital age. As it could be expected, other factors are specific for e-professionalism.

It's interesting that item 10 - Sharing privileged patient information on social media without their consent 
is deemed to be inadmissible saturated on factor Dangers of SM rather than Ethical aspects. It is possible that sharing patient information is regarded as a direct danger of social networks, that can lead to further consequences described by other items composing first factor (for example, losing a job), rather than question of ethics. In other words, it's pragmatic question that can directly impact student's life and not moral or ethical opinion that indirectly guides decisions. It is also possible that students responded this way because it's preferred answer and acceptable behaviour, but that doesn't mean they will behave accordingly. This is known as "cognitive dissonance" and it's a disconnect between what student thought they would do versus what they thought they should [13, 31]. This inconsistency between attitudes and actions has been observed also elsewhere [32, 33]. However, measuring just e-professional behaviour in students can result in incomplete and problematic results since students don't have regular and uniform contact with patients. They have some contact during practical classes, but they lack practical experiences and quantity of doctor-patient relations. Measuring attitude therefore overcomes this problem, and even though it's not perfect prediction of behaviour, it's a sufficient predictive indicator that can be used for creation of educational policy and guidelines.

Factor Excluding physicians requires further testing. It is possible that the formulation of items was not tailored for students but rather physicians with existing experience of dealing with patients on social networks.

Considering average question scoring, results suggest negative aspects of social media (or dangers of social media) are more emphasized than benefits in this sample. It is visible that students in the sample are very aware of the impact of social media on future employability.

This finding is consistent with White et al. research [28]. It's possible that negative consequences and social media related scandals are far more visible and emphasized in the media than positive examples and potential benefits of social networks. White et al. hypothesized that students face dilemma between sharing personal content that could improve their popularity and reducing risk of unwanted attention, for example from employer. Based on results of this study, in terms of "push" or "pull" reasons, we could say that for students in our sample "push" reasons outweighed "pull".

Bosslet et al. found that the majority of respondents found ethically unacceptable to visit the profiles of patients on SM. Additionally, a majority of students in the sample did not agree it was ethically acceptable to interact with patients on SM, either for social or patient-care reasons [27]. However, in our research respondents were much more ambiguous, which can be seen from average scoring of items 1 through 5 (Table 1) that are much closer to neutral values than agreement.

Some tenants of e-professionalism of medical and dental students are consistent with tenants found in scale for measuring pharmacy student's attitudes towards social media professionalism [17]. For example, topic that tackles role of university in dealing with eprofessionalism measured in Chisholm-Burns et al. scale is consistent with factor Freedom of choice in this instrument. Also, the role of social media in future employability is occurring topic that is unavoidable when assessing attitudes of students.

Students in sample on average stated that they understand what constitutes professional behaviour and clearly expressed rebuff about using sanctions for online behaviour. Even though they stated that they know what constitutes professional behaviour there is some ambiguity underlined because there was not unanimous response on whether it's acceptable to visit patients' profiles or not. This suggests that students in the sample had rather individual concepts of professionalism and what is permissible or not. This clearly calls for the need for teaching e-professionalism during formal education and providing them with an unambiguous perspective on eprofessionalism.'

\section{Limitations}

This study has several limitations. First, all items in this scale were taken from previous researches and therefore some theoretical concepts that would have emerged from traditional operationalization of theoretical concepts might be omitted. Although larger number of factors can be expected in first versions of scale development, it is possible some dissipation of item saturations is the result of that.

Second, Excluding physicians being a dimension itself both in factor analysis and second order factor analysis suggests that there is a possibility that as a dimension measured with these particular items is not a domain of e-professionalism, but rather a different topic that requires its own measuring instrument. Regardless, it's an important theoretical part of e-professionalism because it covers students' autonomy and freedom to use SM regardless the profession. Students can position their attitude in relation to extreme measure of banning or restricting usage of SM to healthcare workers in order to reduce space for unprofessional behaviour. Therefore, removing it completely would damage the content validity of the scale so it was not removed. Perhaps in some future iteration of this scale these two items could be rewritten in order to reflect on particular type of risks instead of the general statement and therefore improving measurement. 
Third, this scale was part of a larger questionnaire and items were measured within different parts, resulting in difference in range of rating scale (four-point and fivepoint). Results of factor analysis were not impaired, but caution is recommended in interpreting average item scoring. Four-point items were recoded into five-point scale without neutral value (value 3 into 4; value 4 into 5). That is reason of increase in standard deviation in those changed items (visible in Table 1). For future usage of this scale we recommend unifying all items on five-point scale.

Fourth, the questionnaire was conducted on Croatian language and although questionnaire was translated by English language experts some of the meaning can be lost or changed. For delicate process of finding underlying dimensions that epistemological differences could impact comparability with other scales.

Fifth, all questions were mandatory in order to avoid missing values. That could result in larger degree of respondents withdrawing from research without completing questionnaire. Unfinished questionnaires could not be collected in online survey platform used (Google Forms).

\section{Conclusion}

SMePROF-student version (SMePROF-S) scale for measuring attitude towards e-professionalism among medical and dental students proved to be valid and reliable. Original version of scale has undergone substantial changes during validation process and final version is composed of 24 items that measure seven dimensions of e-professionalism.

This scale can be used to assess and compare medical students and dental medicine students regarding their attitude towards e-professionalism. This is the first validated scale designed to measure attitude towards eprofessionalism on this specific population and therefore there is room for improvements in the future iterations.

\section{Abbreviations}

RR: Response rate; SMePROF: Social Media e-Professionalism; SM: Social media; UZSDM: University of Zagreb School of Dental Medicine, Croatia; UZSM: University of Zagreb School of Medicine, Croatia

\section{Acknowledgements}

We thank Kristijan Sedak for contribution in development of instruments. We thank all students who participated in the study.

\section{Authors' contributions}

TVR, JV, DR, DJ and LMP conceptualized and developed instrument. All authors engaged in distribution/encouragement for questionnaires completion. MM conceptualized the validation and reliability study with appropriate statistical analysis. The paper was drafted by MM, and all authors contributed to subsequent writing and review. TVR performed constant review and contributed to interpretation of findings. All authors read and approved the final manuscript.

\section{Funding}

This study was funded by the Croatian Science Foundation under project UIP-05-2017 "Dangers and benefits of social networks: E-Professionalism of healthcare professionals - SMePROF".

Availability of data and materials

The datasets used and/or analysed during the current study are available from the corresponding author on reasonable request.

\section{Declarations}

\section{Ethics approval and consent to participate}

Both research and questionnaires were approved by the Ethical board of University of Zagreb School of Medicine, issued on March 22nd 2018 (64101/18-02/01) and Ethical board of University of Zagreb School of Dental Medicine, issued on February 20th 2018 (05-PA-24-2/2018). All participants were informed in guidelines statement that their participation is voluntary and anonymous. All participants gave electronic informed consent to participate before starting the survey.

All methods were carried out in accordance with relevant guidelines and regulations.

\section{Consent for publication}

Not applicable.

\section{Competing interests}

The authors declare that they have no competing interests.

\section{Author details}

${ }^{1}$ School of Medicine, University of Zagreb, Zagreb, Croatia. ${ }^{2}$ School of Dental Medicine, University of Zagreb, Zagreb, Croatia.

Received: 10 November 2020 Accepted: 4 August 2021

Published online: 23 August 2021

\section{References}

1. Hazzam J, Lahrech A. Health care professionals' social media behavior and the underlying factors of social media adoption and use: quantitative study. J Med Internet Res. 2018;20(11):e12035. https://doi.org/10.2196/12035.

2. Kitsis EA, Milan FB, Cohen HW, Myers D, Herron P, McEvoy M, et al. Who's misbehaving? Perceptions of unprofessional social media use by medical students and faculty. BMC Med Educ. 2016;16:67.

3. Ghalavand H, Panahi S, Sedghi S. Opportunities and challenges of social media for health knowledge management: a narrative review. J Educ Health Promot. 2020;9:144.

4. Kaczmarczyk JM, Chuang A, Dugoff L, Abbott JF, Cullimore AJ, Dalrymple J, et al. e-Professionalism: a new frontier in medical education. Teach Learn Med. 2013;25:165-70.

5. ABIM Foundation. American Board of Internal Medicine, ACP-ASIM Foundation. American College of Physicians-American Society of internal medicine, European Federation of Internal Medicine. Medical professionalism in the new millennium: a physician charter. Ann Intern Med. 2002;136:243-6.

6. Shore R, Halsey J, Shah K, Crigger B-J, Douglas SP. AMA Council on ethical and judicial affairs (CEJA). Report of the AMA Council on ethical and judicial affairs: professionalism in the use of social media. J Clin Ethics. 2011;22(2): 165-72

7. Australian and New Zealand Medical Associations. Social Media and Medical Professionalism: a guide to online professionalism for medical practitioners and medical students. 2010. https://ama.com.au/article/social-media-andmedical-profession. Accessed 22 Sep 2020.

8. The British Medical Association. Social media : practical guidance and best practice. 2018. https://www.bma.org.uk/search?query=Social\%20media\%2 OPractical\%20guidance. Accessed 22 Sept 2020.

9. Chretien KC, Tuck MG. Online professionalism: a synthetic review. Int Rev Psychiatry. 2015;27(2):106-17. https://doi.org/10.3109/09540261.2015.10043 05.

10. Facebook Investor Relations. Facebook Q2-2020-Earnings. 30 July 2020. https://s21.q4cdn.com/399680738/files/doc financials/2020/q2/Q2-2020-FBEarnings-Presentation.pdf. Accessed 21 Oct 2020. 
11. Modahl M, Tompsett $L$, Moorhead T. Doctors, Patients \& Social Media. QuantiaMD. 2011;16. http://www.quantiamd.com/q-qcp/doctorspatientsocia Imedia.pdf. Accessed 22 Sept 2020.

12. Fuoco M, Leveridge MJ. Early adopters or laggards? Attitudes toward and use of social media among urologists: urologists' use of social media. BJU Int. 2015;115(3):491-7. https://doi.org/10.1111/bju.12855.

13. Kesselheim JC, Schwartz A, Belmonte F, Boland KA, Poynter S, Batra M, et al. A National Survey of pediatric residents' professionalism and social networking: implications for curriculum development. Acad Pediatr. 2016; 16(2):110-4. https://doi.org/10.1016/j.acap.2015.12.004.

14. Langenfeld SJ, Vargo DJ, Schenarts PJ. Balancing privacy and professionalism: a survey of general surgery program directors on social media and surgical education. J Surg Educ. 2016;73(6):e28-32. https://doi. org/10.1016/j.jsurg.2016.07.010.

15. Laliberté M, Beaulieu-Poulin C, Campeau Larrivée A, Charbonneau M, Samson É, Ehrmann FD. Current uses (and potential misuses) of Facebook: an online survey in physiotherapy. Physiother Can. 2016;68(1):5-12. https:// doi.org/10.3138/ptc.2014-41.

16. Levati S. Professional conduct among registered nurses in the use of online social networking sites. J Adv Nurs. 2014;70(10):2284-92. https://doi.org/1 0.1111/jan.12377.

17. Chisholm-Burns MA, Spivey CA, Jaeger MC, Williams J, George C. Development of an instrument to measure pharmacy student attitudes toward social media professionalism. Am J Pharm Educ. 2017;81(4):65. https://doi.org/10.5688/ajpe81465.

18. Nason KN, Byrne H, Nason GJ, O'Connell B. An assessment of professionalism on students' Facebook profiles. Eur J Dent Educ. 2018;22(1): 30-3. https://doi.org/10.1111/eje.12240.

19. Dobson E, Patel P, Neville P. Perceptions of e-professionalism among dental students: a UK dental school study. Br Dent J. 2019;226(1):73-8. https://doi. org/10.1038/sj.bdj.2019.11.

20. Knott PN, Wassif HS. Older and wiser? First year BDS graduate entry students and their views on using social media and professional practice. $\mathrm{Br}$ Dent J. 2018;225(5):437-40. https://doi.org/10.1038/sj.bdj.2018.745.

21. Ahmed H, Soorma T, Nawab F, Ahmed S, Khan O. Survey of medical students' use of social media. Clin Teach. 2016;13(5):392. https://doi.org/1 $0.1111 /$ tct.12544.

22. Barlow CJ, Morrison S, Stephens HO, Jenkins E, Bailey MJ, Pilcher D. Unprofessional behaviour on social media by medical students. Med J Aust. 2015;203(11):439. https://doi.org/10.5694/mja15.00272.

23. Chisholm MA, Cobb H, Duke L, McDuffie C, Kennedy WK. Development of an instrument to measure professionalism. Am J Pharm Educ. 2006;70(4):85. https://doi.org/10.5688/aj700485.

24. Obree D, Trathen A. The special ethics of dentistry. In: Papanikitas A, Spicer J, editors. Handbook of primary care ethics. Boca Raton: FL CRC Press/Taylor \& Francis Group; 2017. p. 385-92. https://doi.org/10.1201/9781315155487-46.

25. Gormley M, Collins L, Schofield S, Neville P. Exploring the impact of digital professionalism awareness training on dental undergraduate students. Eur J Dent Educ. 2021;25:271-81. https://doi.org/10.1111/eje.12601.

26. Project HRZZ: SMePROF: Dangers and benefits of social networks: eprofessionalism of healthcare professionals (SMePROF). School of Medicine University of Zagreb, Croatia. https://mef.unizg.hr/znanost/istrazivanje/webstranice-projekata/projekt-hrzz-smeprof. Accessed 28 Oct 2020.

27. Bosslet GT, Torke AM, Hickman SE, Terry CL, Helft PR. The patient-doctor relationship and online social networks: results of a national survey. J Gen Intern Med. 2011;26(10):1168-74. https://doi.org/10.1007/s11606-011-1761-2.

28. White J, Kirwan P, Lai K, Walton J, Ross S. 'Have you seen what is on Facebook?' The use of social networking software by healthcare professions students. BMJ Open. 2013;3:e003013.

29. Ichikawa N, Yamamoto-Mitani N, Takai Y, Tanaka M, Takemura Y. Understanding and measuring nurses' professionalism: development and validation of the nurses' professionalism inventory. J Nurs Manag. 2020; 28(7):1607-18. https://doi.org/10.1111/jonm.13116.

30. Peacock J, Peacock P. Oxford Handbook of Medical Statistics. 2nd ed. Oxford: Oxford University Press; 2011.

31. George DR, Navarro AM, Stazyk KK, Clark MA, Green MJ. Ethical quandaries and Facebook use: how do medical students think they (and their peers) should (and would) act? AJOB Empirical Bioethics. 2014;5(2):68-79. https:// doi.org/10.1080/23294515.2013.864344.

32. George DR, Green MJ, Navarro AM, Stazyk KK, Clark MA. Medical student views on the use of Facebook profile screening by residency admissions committees. Postgrad Med J. 2014;90(1063):251-3. https://doi.org/10.1136/ postgradmedj-2013-132336.

33. Nagler A, Andolsek K, Rudd M, Sloane R, Musick D, Basnight L. The professionalism disconnect: do entering residents identify yet participate in unprofessional behaviors? BMC Med Educ. 2014;14(1):60. https://doi.org/1 $0.1186 / 1472-6920-14-60$

\section{Publisher's Note}

Springer Nature remains neutral with regard to jurisdictional claims in published maps and institutional affiliations.
Ready to submit your research? Choose BMC and benefit from:

- fast, convenient online submission

- thorough peer review by experienced researchers in your field

- rapid publication on acceptance

- support for research data, including large and complex data types

- gold Open Access which fosters wider collaboration and increased citations

- maximum visibility for your research: over $100 \mathrm{M}$ website views per year

At $\mathrm{BMC}$, research is always in progress.

Learn more biomedcentral.com/submissions 